Food Assistance in Portugal: Organizational Challenges in Three Different Contexts

\begin{tabular}{|r|l|}
\hline Journal: & Journal of Organizational Ethnography \\
\hline Manuscript ID & JOE-08-2020-0029.R2 \\
\hline Manuscript Type: & Research Paper \\
\hline Keywords: & $\begin{array}{l}\text { Food assistance initiatives, Ethnography, State, Organizational } \\
\text { Challenges }\end{array}$ \\
\hline \multicolumn{2}{|l}{} \\
\hline
\end{tabular}

SCHOLARONE ${ }^{\text {m }}$

Manuscripts 


\title{
Food Assistance in Portugal: Organizational Challenges in Three
}

\section{Different Contexts}

\begin{abstract}
:
Purpose - Drawing on an ethnographic research study, developed in three different food assistance initiatives (FAI) operating in Portugal, this article seeks to explore the elements that characterize them and the main organizational challenges they face.

Design/methodology/approach - Participant observation was carried out in a surplus food redistribution charity, a soup kitchen and a social supermarket and semi-structured interviews were conducted with supervisors of these FAI. The study followed an inductive coding strategy and a thematic analysis was developed.

Findings - The main results point to an appreciation of the initiatives and the role they play, but they also highlight the existence of several challenges, mainly related to: i) difficulties in accessing sources of funding; ii) the absence of an intervening state; and iii) a scarcity of resources that allow a thorough assessment of their activities and services provided, which weakens the public image of these responses.

Originality/value - The development of food assistance in Europe has a long history. Over the past few years, this sector has grown significantly. Nowadays, it is possible to identify several realities around emergency food provision. However, this heterogeneity has not been sufficiently explored in the literature. In addition, there are few studies that report on the variety of initiatives that co-exist in Portugal and establish a comparison between them. The current paper intends to overcome this gap by seeking to understand the main models of food assistance operating in the country.
\end{abstract}

Keywords Food assistance initiatives, Ethnography, State, Organizational Challenges

Paper type Research paper 


\section{Introduction}

In the context of the economic and financial crisis that would lead Portugal to request financial assistance from the Troika (International Monetary Fund, European Central Bank and European Commission), in 2011, several measures were taken in order to reduce the welfare state's expenses regarding social benefits. These have covered various types of support such as family benefits, unemployment benefits and social integration income (Rodrigues et al., 2016). Indeed, the state has stepped back in the provision of social support and has transferred to the civil society and the so-called third sector the responsibility of minimizing the adverse effects of the crisis (Lima and Oliveira, 2015).

As a result of the economic and financial crisis and with the increase in unemployment, poverty and social exclusion, the living conditions of Portuguese families worsened considerably, especially between 2011 and 2014 (Almeida, 2016). In this context, the role of food assistance initiatives (FAI), as well as issues related to the importance of combating or at least minimizing poverty and reducing food waste, have become particularly prominent (Dowler and O'Connor, 2012; Truninger et al., 2013). In view of the state's inability to respond to requests for food assistance from the population, the so-called 'third sector' has assumed particular importance. The Catholic Church and its long tradition of solidary and charitable action in the Portuguese context remained relevant (Almeida, 2011). The role played by Food Bank Against Hunger, which represents the main non-governmental organization working in Portugal in this area, also stands out. Data collected by the Portuguese Federation of Food Banks show that food aid went from 249,593 people assisted in 2008 to 384,930 people in 2014 . Regarding the number of active institutions supported by Food Banks, this figure has also increased from 1,528 institutions in 2008 to over 2,600 in 2014 (Portuguese Federation of Food 
Banks, 2015). Currently, in light of the COVID-19 crisis, aid requests to the Portuguese Food Bank have increased significantly, in March and April 2020 more than 11,600 requests were registered (Gaudencio, 2020).

Although food banks represent the most widespread food assistance model in the world, other organizations with different ways of acting have emerged (Hebinck et al., 2018), particularly during the Portuguese crisis of 2011, as is the case with surplus food redistribution initiatives (Truninger et al., 2019). During this troubled period, other Portuguese initiatives, such as the well-known soup kitchens, consolidated and reinforced their intervention (Botelho et al., 2016). Thus, it is possible to find different realities, based on different ideologies and modus operandi. However, this heterogeneity has not been sufficiently explored in the literature (Valenzuela-garcia et al., 2019). Furthermore, there is a lack of comparative studies on these initiatives, as well as a paucity of research that give voice to 'less obvious' actors such as supervisors (Cloke et al., 2017). The current paper intends to overcome this gap by examining three of the main models of food assistance operating in the area of Lisbon, Portugal. Drawing on the analysis of three FAI (a surplus food redistribution charity, a soup kitchen, and a social supermarket), this article will explore the elements that characterize them and the main organizational challenges they face. It is thus expected to contribute to identifying and exploring the diversity of approaches and practices around the provision of food assistance.

\section{Framing the debate: understanding food assistance initiatives}

'Food assistance' can be defined as a set of services aimed at providing food to people who are experiencing difficulties. It is usually provided by civil society initiatives (Hebinck et al., 2018) in emergency situations and is distinguished from the social protection provided by the state (Lambie-Mumford and Dowler, 2014; Poppendieck, 
1994). This kind of support usually involves the donation of food which can be combined with the collection and redistribution of food surpluses that are not included in the usual commercialization processes (Garrone et al., 2014). Food banks represent one of the world's most widespread food assistance models (Hebinck et al., 2018).

FAI were originally created to deal with emergencies, ensuring access to food for a short period of time so that beneficiaries could wait for other types of support (longterm), usually provided by the state. However, what happened was a continuation of these types of initiatives and the support they provided, which stimulated several debates (Lambie-Mumford, 2013). In fact, citizen-led food assistance is increasingly gaining a prominent role. Several initiatives that come from civil society have become institutionalized and there is, currently, a strong industry around food assistance (Lupton, 2011). This led to a process of professionalization of charity and to the emergence of new financing dynamics (e.g. the need for external funding) for several of the organizations that integrate this sector (Valenzuela-garcia et al., 2019).

Despite their long history and the wide range of human and financial resources they have mobilized, FAI do not gather consensus around their role (Cloke et al., 2017; Livingstone, 2015). While, on the one hand, they are considered to be a useful and effective instrument in the fight against poverty and food insecurity (Gentilini, 2013; Lindberg et al., 2015), on the other they are seen as a false, wrong or insufficient strategy to deal with these highly complex and structural social problems. The criticisms usually focus on the nutritional inadequacy of donated foods, on the cost to the human dignity of the beneficiaries and on the dependency generated (van der Horst et al., 2014; Mirosa et al., 2016; Poppendieck, 1999; Vlaholias et al., 2015).

In addition, there is also no consensus on the relationship between food assistance and the state. In this regard, it is possible to identify those who interpret food assistance 
practices as signs of the 'failure of the state' and those who consider the articulation between the FAI and the state to be natural and positive (Hebinck et al., 2018; Schoneville, 2018). The first perspective integrates a set of different academic discussions, namely: i) food sovereignty; ii) food justice; iii) Right to Food; and Food Security (see Lambie-Mumford and Silvasti, 2020; Williams et al., 2016).

Although these theoretical contributions help to systematize the main arguments that can be found in the literature on food assistance, they only reveal the poles around a problem that is much more complex and that cannot be reduced to dualist perspectives. In fact, FAI are ambivalent 'spaces of care' that incorporate various tensions and contradictions within themselves: "between shame and gratitude, stigma and acceptance, moral judgement and emotional support" (Cloke et al., 2017, p. 714). In view of this, it is necessary to explore the diversity of organizations that are part of the universe of food assistance (Valenzuela-garcia et al., 2019) and understand the practical implications of their activities (Mirosa et al., 2016).

Recent studies have integrated the perspective of the various stakeholders of FAI (e.g. beneficiaries, volunteers, supervisors and retailers) by adopting micro and/or bottom-up approaches (e.g. Hebinck et al., 2018; Mirosa et al., 2016; Thompson et al., 2018; Wills, 2017) to capture the complexities inherent to these organizations (see, e.g. Valenzuela-garcia et al., 2019). Such approaches allow the analysis of FAI by taking into account their geographical and socio-cultural contexts (Galli et al., 2016).

In the Portuguese context, despite the existence of significant social inequalities, few studies have been conducted regarding the food insecurity situation of the population (Gregório et al., 2014). There is also a lack of studies on the characterization and evaluation of food assistance programs and initiatives in the country (Pais and Ferreira, 2016). Recent data indicates a prevalence of food insecurity amongst Portuguese families 
of around 12\% (IAN-AF, 2017; Truninger et al., 2019). Regarding the characterization of food assistance in Portugal, it is possible to highlight the programs that are promoted by the state (e.g. Food Emergency Program ${ }^{1}$ ) and the initiatives that arise from civil society (e.g. food banks and soup kitchens) (Almeida, 2016; Botelho et al., 2016). It is also important to highlight the role played by the Catholic Church in the development of food assistance in the country.

In this regard and as mentioned by Almeida (2011), the evolution of the third sector in the countries of the Mediterranean model is characterized by the absence of separation between state and the Catholic Church. In the Portuguese context, mercies are one of the main examples of the strong collaboration between these two entities. The absence of a liberal tradition since the 19th century and throughout the dictatorial period (1926-1974), would eventually lead the Catholic Church to assume a quasi-public status and an enormous centrality in the provision of social services. After the establishment of democracy and profound political, economic and social changes, Portugal continued to be characterized by a strong relationship between State - Church - Third sector.

Over the past 20-30 years in Europe, there has been an increase in food charity associated with changes in welfare states and social policies (Lambie-Mumford and Silvasti, 2020). In fact, the neoliberal ${ }^{2}$ wave and the ideas of private responsibility, recommodification and deregulation (Harvey, 2005) have been strongly influencing food assistance. In this context, states have been delegating responsibilities to the charitable sector (Lambie-Mumford and Silvasti, 2020). With the 2008 international economic crisis, social protection was severely restricted. During the crisis, particularly during the

\footnotetext{
${ }^{1}$ A program created by the Portuguese government that sought to ensure daily meals for economically deprived families.

${ }^{2}$ A political ideology that defends the rights to private property, free trade and free markets. According to neoliberalism, the state must not assume a decisive role in relation to the regulation of markets (Harvey, 2005).
} 
PSD/CDS-PP coalition government (2011-2015), there was a strong public disinvestment in social protection policies in Portugal (Truninger et al., 2019).

In view of this, various types of FAI have emerged in the country and 'traditional' models (e.g. food banks and soup kitchens) coexist with 'alternative' models (e.g. surplus food redistribution initiatives and social supermarkets) (Lima and Oliveira, 2015; Truninger et al., 2019). However, the heterogeneity and diversity of approaches and practices around the provision of food assistance remains largely unexplored (Pais and Ferreira, 2016). This article intends to understand how some (of the main) Portuguese food assistance models operate and the main organizational challenges they face. This analysis will offer the opportunity to comprehend some of the social, institutional, and political dynamics associated with the complex universe of food provision.

\section{Methodology}

This article results from a $\mathrm{PhD}$ qualitative research study that unfolded in two phases. In the first phase, the researcher carried out ethnographic work for approximately three months in each of the three initiatives under analysis (a surplus food redistribution charity, a soup kitchen and a social supermarket), thus totaling nine full months, which allowed for both an understanding of the reality of the initiatives and the creation of proximity with its actors ${ }^{3}$ so that, in a second phase, it was possible to carry out 39 semistructured interviews with supervisors (3), volunteers (18) and beneficiaries (18) of the FAI. The selection process of the initiatives essentially took into account two criteria: i) the fact that they represent three of the main models of food assistance operating in the country; ii) and the fact that they are at different stages of development.

\footnotetext{
${ }^{3}$ The ethnographic approach also allows focusing on the relationship established between the micro, meso, and macro levels of research (Valenzuela-garcia et al., 2019).
} 
The interviewees were selected through a 'contrast' technique (Guerra, 2006), aiming to create a sample mosaic that captured the diversity of the population (volunteers and beneficiaries). Ethical clearance was obtained from the Ethics Committee of the host institution of the $\mathrm{PhD}$ project. Cooperation protocols were created and signed with supervisors of the initiatives in order to: i) guarantee access to the field of research through volunteering and ii) preserve the integrity of the organizations by ensuring participants' anonymity and data confidentiality. Written informed consent was obtained for the interviews on the understanding that participation in the study was voluntary and that participants would be de-identified.

Fieldwork (participant observation and semi-structured interviews) was initiated in February 2018 and completed in March 2019. All the interviews were recorded with participants' consent. For this article, the analysis focuses on the data collected during the ethnographic research phase - through the analysis of field notes - and on the semistructured interviews conducted with the FAI supervisors ${ }^{4}$. These data were analyzed using MAXqda2007 software and a thematic analysis was developed. An inductive coding strategy was followed, where themes where determined beforehand based on previous theory and empirical research.

\section{Brief characterization of the food assistance initiatives}

In Portugal, as in other European Union countries, there are several food assistance programs and initiatives that come from the state and/or civil society (Botelho et al., 2016). Among the various types/models of food assistance that can be found in the country, it is possible to highlight three initiatives: i) soup kitchen; ii) social supermarket and iii) surplus food redistribution charity. By representing three of the main food

\footnotetext{
${ }^{4}$ Pseudonyms will be used throughout the article to identify the supervisors.
} 
assistance models operating in Portugal (Botelho et al., 2016) and by articulating themselves with other initiatives and programs in the area of food poverty/insecurity, they provide some important clues about the reality of food assistance in the Portuguese context. To this end, three centres of these initiatives were analyzed (see table I), all located in the district of Lisbon.

Please insert table I here - "Characterization of the initiatives (2018)"

The Soup Kitchen ${ }^{5}$ was officially inaugurated in 2000 and since then it has provided food support to the region's homeless population. The support is focused on providing a space and all the conditions necessary to enable the beneficiaries to have access to four meals a day (breakfast, lunch, snack and dinner) and to have access to public and private entities (e.g. for obtaining subsidies and medical consultations). In 2012, the initiative became part of the Food Emergency Program and started distributing meals to low-income families identified by Social Security. In this case, the initiative only provides food support, giving the same four meals a day (to be consumed at the beneficiaries' home).

As with the Soup Kitchen, the Social Supermarket is also associated with an established entity, namely a Catholic Church located in the district of Lisbon, and was formally launched in 2016. Basically, it is a space similar to a conventional supermarket with shelves, refrigerators, service counters and varied types of food and hygiene products. What distinguishes this supermarket from the rest is its main goal: to help those who need it most. Thus, the non-profit initiative works through a system of credits that serve as trading currency, that is, each family has a card with a number of monthly credits

\footnotetext{
${ }^{5}$ It is financially supported by a Holy House of Mercy.
} 
(to be decided by those responsible) that can be exchanged for the products from the Social Supermarket (each product has an associated number of credits). The initiative is informed by Christian values but does not restrict its support only to believers.

In 2011, the Surplus Food Redistribution Charity, based on the idea of combatting food waste, was officially created in Lisbon and started operating in a space provided by a Catholic Church that distributed the food items collected in local restaurants and cafes. The initiative's volunteers took over the entire process of collecting, packing and distributing food donations. Over a period of five years (2011-2016), the initiative has grown significantly and has expanded nationwide. Volunteers can collect food on foot, by bicycle or by car. The beneficiaries can either be occasional (those who address the initiative sporadically) or regular (those who are enrolled in the initiative and use it with some frequency). In situations of reduced mobility, the initiative makes deliveries at home. There are also defined distribution points, usually places that do not have a centre of the surplus food redistribution initiative nearby.

\section{Findings}

The results presented in this section seek to explore some of the main food assistance models operating in Portugal and account for the elements of continuity and differentiators that characterize them. Throughout the various interactions with the supervisors of the analyzed initiatives, several organizational challenges were identified, mainly related to: i) access to sources of funding; ii) the role played by the state; and iii) the assessment of the activity and services provided. These challenges allow the exploration of some of the main organizational dynamics that FAI (re)produce in the Portuguese context. 


\section{Access to sources of funding}

During the fieldwork and in the contact with the supervisors of the initiatives some keywords emerged in their speeches and informed the field notes:

Field Notes, Surplus Food Redistribution Charity

9 April 2018

Today, I had the opportunity to talk to the initiative supervisor (Thomas) and a group of volunteers. The conversation lasted about $15 \mathrm{~min}$. and focused on the elements that make the surplus food redistribution initiative a unique organization. It is not the first time that I have heard this speech and I must admit that I am intrigued by this need to highlight the differentiating aspects of the initiative...

Words like 'alternative', 'innovative' and 'different' seemed to refer to a need on the part of the supervisors to justify to others the differentiating character of their initiative. This need was expressed during the volunteer work developed by the researcher and amplified in the interview context. The successive formulation of applications and the need to justify the value of the initiative and its differentiating nature seem to have led to the adoption of a discourse by the supervisor of the Surplus Food Redistribution Charity around the words mentioned above. Also, in the case of the Soup Kitchen, despite being financed by a Holy House of Mercy, this type of discourse was very much embedded, which can be explained by the successive attempts to acquire external financing. In the case of the Social Supermarket, this type of discourse was more absent, which could be due to the lack of applications for other types of financing, thanks to the financial autonomy guaranteed by the church ${ }^{6}$.

In fact, issues related to access to funding sources ended up dominating the narratives of the supervisors of the initiatives, representing one of the main organizational

\footnotetext{
${ }^{6}$ However, the supervisor also expressed some concern about the future of the initiative, as the church was overcoming some serious financial difficulties.
} 
aspects discussed during the fieldwork. As it is a topic that has a profound impact on the survival and management of initiatives, supervisors are focused on ensuring the maximum possible support.

The inadequacy of the funding networks already achieved is identified by the three supervisors of the FAI. The Surplus Food Redistribution Charity began its activity with $600 €$. This first investment served to buy plastic packaging to carry out the collection of food. Since then, the initiative has received the financial support of several entities. The partnerships created depend on the geographical context in which the centres are implemented, so the initiative has already had, for example, support from city councils, parish councils and banks. These entities, generally, can provide space, equipment or financial resources. However, establishing partnerships with food sources, i.e. places such as restaurants and cafes ${ }^{7}$ are central to the initiative. In addition to this type of support, the Surplus Food Redistribution Charity has been participating in several competitions that award monetary prizes. The commitment of this initiative to applications for national and international funding sources is highly valued by the leading members:

I create the vision for the application, but we also have professional help from a team...and we won a lot...recently in Europe 2020 we won about $40.000 € \ldots$... think we know how to win applications. (Thomas, Surplus Food Redistribution Charity)

The Soup Kitchen does not emerge as an independent project, as is the case with the Surplus Food Redistribution Charity. The initiative is created with the purpose of extending the scope of action of a Holy House of Mercy and, as such, is supported by it through human, financial and material resources. Since its inception, the initiative has had two key partners, namely the Parish, which has made available one of the spaces where

\footnotetext{
${ }^{7}$ Spaces that generate food waste.
} 
the initiative operates, and the Parish Council, which provided initial support through the provision of public baths to the beneficiaries. In addition to these partners, and since it is an initiative that closely monitors the beneficiaries, they are supported by other entities:

Then we have partners at the technical level, in this case the city council, the health centre, mental health centre, public health institutions, a support centre for the homeless, which signals and accompanies them...and the municipal police...this is all technical support, then we have monetary support, for example we have occasional donations from companies. (Hannah, Soup Kitchen)

As was the case with the Soup kitchen, the Social Supermarket also began its activity by being associated with an institution, in this case, a Catholic Church that provides space and guarantees its maintenance. The Food Bank guarantees weekly support for this initiative (the type and quantity of products vary). During fieldwork, the researcher closely followed some collections and found that, generally, the products fill the base of an open box van and can include pasta, rice, tuna and a range of fruit. The initiative also collects food from a supermarket chain, usually cakes, bread and vegetables. As a way to raise money for food purchases, the initiative runs various types of events, such as organizing theme parties or selling products created by volunteers. Occasionally, the initiative receives donations from community members, this support may be financial or in kind.

As can be seen, the three initiatives have different origins and mobilize the resources they hold in different ways. It is interesting to note the Surplus Food Redistribution Charity's capacity to guarantee the subsistence of a $100 \%$ voluntary organization, by establishing a considerable number of multi-level partnerships, as well as its commitment to seek national and international funding. 
Despite the partnerships and the resources mobilized, the three initiatives have already faced situations in which the service provided by them was strongly conditioned. The Soup Kitchen faced serious financial difficulties during the Portuguese crisis of 2011, when it had to reduce the number of beneficiaries. The Social Supermarket has already faced severe stock-outs, having been without important products (e.g., fruit, vegetables, and fish) for several consecutive weeks. The supervisor of the Surplus Food Redistribution Charity also mentioned the lack of essential products such as milk, yoghurts, and vegetables. In addition, this initiative also faced challenges related to the lack of volunteers to carry out the collection, preparation, and delivery of food, especially during the summer holidays.

\section{The role played by the state}

Another organizational challenge identified by the supervisors of the initiatives relates to the role of the state in terms of the provision of food assistance. In this regard, the positions adopted by the supervisors are not consensual, with variations regarding accountability and the type of relationship established with the third sector.

According to the Surplus Food Redistribution Charity supervisor, the state is seen as a partner of the initiative that has been contributing through the concession of spaces of action and of food sources (e.g., public canteens):

The state offers spaces, the hospital belongs to the Ministry of Health...the state is our partner. (Supervisor, Surplus Food Redistribution Charity)

Regarding the role that the state should play in food assistance, the supervisor stated:

I think the real role of the state is to facilitate what civil society can do, because the state cannot...the government cannot do it, but civil society can... and this is a very important thing...the citizens have immense power 
but they do not know it ... we have the power to end food waste and hunger in our community. (Thomas, Surplus Food Redistribution Charity)

There is, therefore, a view of the role of civil society based on the assumption that it has the power and capacity to address problems to which the state cannot respond. The perspective assumed here by Thomas seems to be close to those who see FAI as an extension of the state and as facilitators of their action.

The Soup Kitchen supervisor expresses a different perspective in relation to the role of the state. Faced with the question: 'Do you consider that the state has an active role in improving the living conditions of the most economically disadvantaged individuals/families?', the supervisor replied in a negative way:

No, the state is, increasingly, passing on responsibilities to the IPSS [Portuguese Private Institutions for Social Solidarity] ... the state has no capacity for more...cannot! ... but then it also does not give support to institutions to play its role...the state could support more financially... (Hannah, Soup Kitchen)

While in the speech of the Supervisor of the Surplus Food Redistribution Charity there was a certain process of 'accountability' of civil society, in the case of the supervisor of the Soup Kitchen this responsibility is directed to the state. That is, if it is unable to act, it should at least guarantee institutions more tools to do so. Despite this perspective, the Soup Kitchen was collaborating with the state through the Social Emergency Program (PES), a political measure of the Portuguese coalition government PSD/CDS-PP (started in 2011) that guaranteed the financing of meals for 10 of the 28 beneficiaries of the initiative.

Contrary to what happened in the other analyzed initiatives, the Social Supermarket did not establish any type of partnership with the state, operating independently from this entity. On this matter, the supervisor stated: "we never received 
any support from the state ... until now we have never counted on it for anything". Regarding the role of the state, the supervisor stated the following:

The state should give other types of support to this type of institution, it should know the projects a little more...it should talk to us to know what we need. (Lucie, Social Supermarket).

This distance between the initiative and the state was also underlined by several volunteers in this food response. Some of them even said that it is a shame to have a state that does not understand the reality of their country and the initiatives that struggle every day to help those in need. In this regard, the Social Supermarket supervisor adds:

It is up to the state to learn about the various FAI operating on the ground and to coordinate its efforts ... the state must be able to support initiatives during all phases of its development (Lucie, Social Supermarket).

This speech is particularly interesting because it attributes to the state responsibilities related to the coordination of the various initiatives operating in the field. In fact, all supervisors interviewed considered that there are coordination and communication problems between the various FAI operating in the Portuguese context. During his interview and several informal conversations, the supervisor of the Surplus Food Redistribution Charity warned against this reality, pointing out that there are certain areas of Lisbon that are covered by various initiatives providing the same type of support, while there are other areas which are not covered by any type of food support. The Soup Kitchen supervisor also expressed concern about the lack of communication between organizations and the unnecessary repetition of efforts:

Sometimes it seems that we are all reinventing the wheel ... if all food assistance organizations made their strategies known, we would all win and could provide a higher quality service ... (Hannah, Soup Kitchen). 
According to the supervisors, the state should act as a mediator and articulator of efforts between the various FAI operating in Portugal. This idea was also shared by several volunteers from the analyzed initiatives.

Field Notes, Social Supermarket

14 March 2019

Today was my last day of volunteering, I finished the fieldwork in the organizations. Several volunteers asked me about the next steps in my research and the practical results of it. Even before I could answer, the volunteers asked me to inform the state of the need for it to support the initiatives more and to coordinate efforts between them. This reaction is very interesting and is transversal to the various initiatives analyzed.

In general, the supervisors of the analyzed initiatives have different conceptions about the role of the state in terms of food assistance and about the relationship that it should establish with civil society and the so-called third sector to tackle the problems of poverty and food insecurity.

\section{The assessment of the activity and services provided:}

When the supervisors were questioned about the impact their initiatives have been having, as well as their ability to meet their defined objectives, in all three cases, there were strong convictions about the existence of a positive and beneficial impact on society. However, these convictions are not, in certain situations, based on concrete data, which makes it difficult to assess the actual impact of these initiatives, as well as the activity and services provided. The Soup Kitchen was the only initiative that was able to identify the number of beneficiaries (20 out of 200) who succeeded in being reintroduced into society and who no longer needed to resort to this social response. 
During the fieldwork, both the supervisor and several volunteers from the Surplus Food Redistribution Charity and Social Supermarket expressed their willingness to implement accounting tools that would make it possible to identify the beneficiaries who were reintegrated, as well as the products and volunteers who enter and leave the initiative.

Field Notes, Surplus Food Redistribution Charity

22 February 2018

While attending to a beneficiary, I noticed a conversation between two volunteers about the products that had just arrived at the initiative. The volunteers reported that it was difficult to manage all products and their expiration dates without a clear and effective accounting system.

The Surplus Food Redistribution Charity supervisor spoke about the possibility of implementing a digital application in the near future that will allow the necessary accounting to be carried out:

We are developing an application that will allow us to know in real time all products that enter and leave the initiative. In addition, it will also allow us to know exactly how many volunteers and beneficiaries we have. (Thomas, Surplus Food Redistribution Charity).

The Social Supermarket supervisor said that in an initial phase the initiative was able to count the products that entered and left the initiative, thanks to the efforts of one of its volunteers:

At the beginning we had a volunteer who was an IT professional and who developed a product accounting system identical to that of traditional supermarkets, each product had a bar code and we had a program on the computer that allowed us to recognize and enter the codes. Then the volunteer left the 
initiative, and the program was no longer updated. We currently have no system in place. We would like to be able to count products again, but we do not have the knowledge or funds to do so (Lucie, Social Supermarket).

When asked about the existence of records on volunteers and beneficiaries, the supervisor said:

We have some scattered information, nothing is systematized. We do not know, for example, what happened to the beneficiaries who left the initiative...we do not know if it was for good or bad reasons... (Lucie, Social Supermarket).

However, during the contact with the volunteers and beneficiaries of the Surplus Food Redistribution Charity and the Social Supermarket, the researcher became aware of some cases of 'success', usually resulting from reintegration into the labour market. The lack of human and financial resources, as well as tools to assess the impact, the activity and the services provided by these initiatives, could help to 'feed' debates around their role, promoting a negative image. This is particularly evident in the application processes for external funding, in this regard, supervisors admit that the lack of concrete data on products, human resources and beneficiaries compromises the quality of the application.

\section{Discussion}

The debates around FAI are part of a kind of continuum that ranges from critical perspectives to perspectives that support their existence and value these organizations (Hebinck et al., 2018; Vlaholias et al., 2015). In addition, studies on the heterogeneous universe of food assistance in Portugal are still scarce (Pais and Ferreira, 2016). In view of these debates and heterogeneity, it was interesting to capture the point of view of those who work in the field, in particular, the supervisors of the initiatives. There was a strong need (on the part of the supervisors) to raise awareness of the differentiating aspects of 
the initiatives and the importance of their action. This need may be related to the phenomenon of professionalization of charity, where the withdrawal of the state leads the organizations of the third sector to seek financial support from other sources (e.g. companies and contests), leading to the need to differentiate between them (Valenzuelagarcia et al., 2019).

Despite this process of professionalization and the existence of a wide industry around food assistance (Lupton, 2011), the analyzed initiatives face serious difficulties in managing and obtaining sources of funding. The lack of human, financial and material resources leads these initiatives to provide, in several situations, a precarious service. This calls into question the capacity of these responses to promote social justice, based on the principles of equality and human dignity (Lambie-Mumford and Silvasti, 2020).

In addition, the absence of data on the activity and services provided by the initiatives, such as the number of beneficiaries who have been reinstated in the labour market, contributes to the weakening of the supervisors' discourse, as well as the public image of the organizations analyzed. This precludes a true assessment of the impact of these types of initiatives and promotes the existence of different positions around their social role (Vittuari et al., 2017). In this regard, Mirosa and colleagues (2016) highlight the importance of exploring the social value created by these responses. According to the authors, this knowledge could, eventually, even help in obtaining funding.

The presence of the Catholic Church in the Portuguese context becomes clear in relation to the three cases analyzed, all of which, more or less directly, relate to this entity. Although not all initiatives are oriented exclusively by Christian values, the church represents an important landmark in food assistance in Portugal. Indeed, the Catholic Church has a long history of collaboration not only with the third sector, but also with the state, thereby securing public and private funds (Belzunegui-Eraso et al., 2019). With the 
economic crisis of 2008 and the introduction of several neoliberal policies, food charity increased (Lambie-Mumford and Silvasti, 2020) and the Catholic Church was once again called upon to intervene (Truninger et al., 2019).

In fact, with the retreat of the state both the Catholic Church and civil society were put under pressure (Rosa, 2016; Silva, 2012). Since the initiatives that emerge from these entities are not governed by the same public sector obligations (based on the fulfillment of social rights), they can contribute to reinforcing social exclusion and inequality between beneficiaries. The aforementioned limited resources available to this type of organization can jeopardize the universality of the services provided, as well as the wellbeing of the beneficiaries. This raises several questions related to the role of the state (Lambie-Mumford and Silvasti, 2020).

The state is seen by the supervisors of the initiatives under discussion as an element with no capacity to act. In the Surplus Food Redistribution Charity case, there is an acceptance of this reality and an understanding that part of the responsibility lies with civil society and the so-called third sector. On the other hand, both the head of the Soup Kitchen and the Social Supermarket believe that the state should have a more active role, mainly in terms of financial support for initiatives already in the field. The lack of a regulatory authority of FAI contributes to these responses acting in an operational vacuum, where there is an overlap of support in the same space and a scarcity of support in another. It is considered that the role of the state could, precisely, be to serve this lack, acting as a mediator and articulator of efforts.

The different perspectives of supervisors are in line with the debates identified by Hebinck and colleagues (2018, p. 400). If, on the one hand, the existence of food assistance can be interpreted as 'a failure of the state', on the other, it can represent 'an extension of the welfare state'. Regarding the second perspective, it is also important to 
highlight the contribution of Schoneville (2018) when he mentions the existence of a 'new' model of welfare state, stating that "the charity economy itself has become an integral part of the modern welfare (state) arrangement" (2018, p. 1). While Thomas seems to agree with these new institutional arrangements, Hannah and Lucie adopt a more critical perspective on the role of the state in matters of food assistance.

\section{Conclusions}

With the economic and financial crisis that was felt in Portugal, especially between 2011 and 2014, the living conditions of the population worsened and the state reduced the support provided (Rodrigues et al., 2016). This retreat led to the consolidation and emergence of several FAI (Lima and Oliveira, 2015). The largest food assistance organization acting at national and international levels, the food bank, has, during the crisis, supported more people and institutions (Hebinck et al., 2018). In addition, initiatives such as the Surplus Food Redistribution Charity have emerged to work in the fight against food poverty and food waste.

In the light of the discourses of the supervisors interviewed for this study, FAI represent a valuable alternative in face of the lack of state support. The Catholic Church seems to play an important role in the development of these initiatives even if not all of them appeared to be informed by Christian values. This can be explained by the Portuguese context, which has been characterized by a strong presence of the Catholic Church in social assistance issues and by a specific kind of solidarity based on informal social networks (e.g. family and friends) that may eventually complement state support (Truninger et al., 2019).

In addition to the absence of the state in terms of food assistance provision, the supervisors also mentioned organizational challenges related to difficulties in managing 
and accessing sources of funding and difficulties in assessing the activity and services provided. This last challenge contributes not only to compromise the assessment of the impact of these types of initiatives, but also weakens their public image and promotes the existence of different postures around their social role.

Overall, this article sought to explore some of the main food assistance models operating in Portugal, as well as the main organizational challenges faced by these social responses. The lack of state support and the difficulties that the analyzed initiatives face in guaranteeing their sustainability raises several ethical and practical questions. It is important and urgent to define government action strategies that are not just based on the transfer of responsibilities to the third and charitable sector, which jeopardizes the principles of universality, equality, and social justice. Currently, with the Coronavirus epidemic, it is believed that these challenges will become more pronounced, so it is important to continue to study this heterogeneous and volatile universe.

\section{References}

Almeida, V. (2011), As Instituições Particulares de Solidariedade Social - Governação e Terceiro Sector, Almedina, Coimbra.

Almeida, V. (2016), 'Portuguese Private Institutions for Social Solidarity in the Context of Austerity: The Network of Social Canteens', Interações: Sociedade e as Novas Modernidades, No. 30, pp. 5-23.

Belzunegui-Eraso, A., Duenas-Cid, D. and Pastor-Gosálbez, I. (2019), 'Religious social action and its organizational profiles: Study conducted in the context of southern European welfare states', Journal of Organizational Ethnography, Vol. 8 No. 1, pp. $95-108$.

Botelho, A., Pinto, A.H., Almeida, C. and Pereira, J. (2016), 'Os programas de apoio 
alimentar em Portugal: caracterização e desafios para o futuro', in Castanheira, S. and Ferreira, P.D. (Eds.), A Redução Das Assimetrias Sociais No Acesso à Alimentação e à Saúde: Políticas e Práticas, Mais leitura, Porto, pp. 71-84.

Cloke, P., May, J. and Williams, A. (2017), 'The geographies of food banks in the meantime', Progress in Human Geography, Vol. 41 No. 6, pp. 703-726.

Dowler, E. and O’Connor, D. (2012), 'Rights-based approaches to addressing food poverty and food insecurity in Ireland and UK', Social Science and Medicine, Vol. 74 No. 1, pp. $44-51$.

Federação Europeia de Bancos Alimentares. (2015), 'Pessoas assistidas', available at: goo.gl/S92Zj9 (accessed 8 March 2015).

Galli, F., Hebinck, A., Arcuri, S., Brunori, G., Carroll, B., O’Connor, D. and Oostindië, H. (2016), 'The food poverty challenge: comparing food assistance across EU countries. A Transformative Social Innovation perspective', Proceedings of the SIDEA Conference, San Michele, Italy.

Garrone, P., Melacini, M. and Perego, A. (2014), 'Surplus Food Recovery and Donation in Italy: The Upstream Process', British Food Journal, Vol. 116 No. 9, pp. 14601477.

Gaudencio, R. (2020), 'Milhares de famílias caídas na pobreza pedem ajuda. Banco Alimentar nunca viu nada assim', PÚBLICO, Lisboa, available at: https://bit.ly/30rZ8Ki.

Gentilini, U. (2013), 'Banking on Food: The State of Food Banks in High-income Countries', IDS Working Papers, Vol. 2013 No. 415, pp. 1-18.

Gregório, M.J., Graça, P., Costa, A. and Nogueira, P.J. (2014), 'Perspectivas temporais e regionais da insegurança alimentar durante a crise econômica em Portugal, 20112013', Saúde e Sociedade, Vol. 23 No. 4, pp. 1127-1141. 
Guerra, I. (2006), Pesquisa Qualitativa e Análise de Conteúdo: Sentidos e Formas de Uso, Princípia, Cascais.

Harvey, D. (2005), A Brief History of Neoliberalism, Oxford University Press, Oxford. Hebinck, A., Galli, F., Arcuri, S., Carroll, B., O’Connor, D. and Oostindie, H. (2018), 'Capturing change in European food assistance practices: a transformative social innovation perspective', Local Environment, Vol. 23 No. 4, pp. 398-413.

van der Horst, H., Pascucci, S. and Bol, W. (2014), 'The "dark side” of food banks? Exploring emotional responses of food bank receivers in the Netherlands', British Food Journal, Vol. 116 No. 9, pp. 1506-1520.

IAN-AF. (2017), Inquérito Alimentar Nacional e de Atividade Fisica 2015-2016, Universidade do Porto, Porto.

Lambie-Mumford, H. (2013), “"Every town should have one”: Emergency food banking in the UK', Journal of Social Policy, Vol. 42 No. 1, pp. 73-89.

Lambie-Mumford, H. and Dowler, E. (2014), 'Rising use of " food aid " in the United Kingdom', British Food Journal, Vol. 116 No. 9, pp. 1418-1425.

Lambie-Mumford, H. and Silvasti, T. (2020), 'Introduction: exploring the growth of food charity across Europe', in Lambie-Mumford, H. and Silvasti, T. (Eds.), The Rise of Food Charity in Europe, Policy Press, Bristol and Chicago, pp. 1-18.

Lima, A.P. de and Oliveira, F.M.R. (2015), 'O valor do tempo. Dádiva e voluntariado em Portugal em tempos de crise', Interseções: Revista de Estudos Interdisciplinares, Vol. 17 No. 2, pp. 300-326.

Lindberg, R., Whelan, J., Lawrence, M., Gold, L. and Friel, S. (2015), 'Still serving hot soup? Two hundred years of charitable food sector in Australia: a narrative review', New Zealand Journal of Public Health, Vol. 39 No. 4, pp. 358-365. Livingstone, N. (2015), 'The Hunger Games: Food poverty and politics in the UK', 
Capital and Class, Vol. 39 No. 2, pp. 188-195.

Lupton, R. (2011), Toxic Charity: How the Church Hurts Those They Help and How to Reverse It, Harper Collins Publishers, New York.

Mirosa, M., Mainvil, L., Horne, H. and Mangan-Walker, E. (2016), 'The social value of rescuing food, nourishing communities', British Food Journal, Vol. 118 No. 12, pp. 3044-3058.

Pais, S.C. and Ferreira, P. (2016), A Redução Das Assimetrias Sociais No Acesso à Alimentação e à Saúde: Políticas e Práticas, Journal of Chemical Information and Modeling, Vol. 53, Mais leituras, Porto.

Poppendieck, J. (1994), 'Dilemmas of Emergency Food: A Guide for the Perplexed', Agriculture and Human Values, Vol. 11 No. 4, pp. 69-76.

Poppendieck, J. (1999), Sweet Charity? Emergency Food and the End of Entitlement, Penguin Books, New York.

Rodrigues, C.F., Figueiras, R. and Junqueira, V. (2016), Desigualdade Do Rendimento e Pobreza Em Portugal: As Consequências Sociais Do Programa de Ajustamento, Fundação Francisco Manuel dos Santos, Lisboa.

Rosa, I. (2016), 'Banco Alimentar Contra a Fome apoiou mais 100.800 pessoas nos últimos 4 anos', Observador, Lisboa, available at: https://bit.ly/3t5zcR2.

Schoneville, H. (2018), 'Poverty and the transformation of the welfare (state) arrangement . Food banks and the charity economy in Germany', Social Work \& Society, Vol. 16 No. 2, pp. 1-9.

Silva, G. (2012), 'Igreja Católica é “tábua de salvação” para muitas famílias', Diário de Notícias, Lisboa, available at: https://bit.ly/3qqqvPq.

Thompson, C., Smith, D. and Cummins, S. (2018), 'Understanding the health and wellbeing challenges of the food banking system : A qualitative study of food bank 
users, providers and referrers in London', Social Science \& Medicine, Vol. 211, pp. $95-101$.

Truninger, M., Horta, A., Cardoso, S.G., Augusto, F.R., Teixeira, J. and Fontes, A. (2019), Alimentação Em Tempos de Crise: Consumo e Segurança Alimentar Nas Familias Portuguesas, Imprensa de Ciências Sociais, Lisboa.

Truninger, M., Teixeira, J., Horta, A., Alexandre, S. and Silva, V. (2013), 'Estado social e alimentação escolar: criatividade na austeridade', Forum Sociológico, No. 23, pp. $11-19$.

Valenzuela-garcia, H., Lubbers, M.J. and Rice, J.G. (2019), 'Charities under austerity: ethnographies of poverty and marginality in Western non-profit and charity associations', Journal of Organizational Ethnography, Vol. 8 No. 1, pp. 2-10.

Vittuari, M., De Menna, F., Gaiani, S., Falasconi, L., Politano, A., Dietershagen, J. and Segrè, A. (2017), 'The second life of food: an assessment of the social impact of food redistribution activities in Emilia Romagna, Italy', Sustainability, Vol. 9 No. 10, pp. 1-14.

Vlaholias, E., Thompson, K., Every, D. and Dawson, D. (2015), 'Charity starts ... at work? Conceptual foundations for research with businesses that donate to food redistribution organisations', Sustainability (Switzerland), Vol. 7 No. 6, pp. $7997-$ 8021.

Williams, A., Cloke, P., May, J. and Goodwin, M. (2016), 'Contested space: The contradictory political dynamics of food banking in the UK', Environment and Planning A, Vol. 48 No. 11, pp. 2291-2316.

Wills, B. (2017), 'Eating at the limits: Barriers to the emergence of social enterprise initiatives in the Australian emergency food relief sector', Food Policy, Vol. 70, pp. $62-70$. 


\begin{tabular}{l|c|c|c|c}
\multicolumn{1}{c}{ Initiative } & Supervisor & 18 & 28 & 112 per day \\
\hline Soup Kitchen & Hannah & 17 & 150 & No data \\
\hline Social & Lucie & 193 & 1225 & 2103 per month \\
Supermarket & Thomas & & & \\
\hline Surplus Food & & & & \\
Redistribution & & & & \\
\hline
\end{tabular}

Table I. Characterization of the initiatives $(2018)^{1}$.

\footnotetext{
${ }^{1}$ The data reported by the supervisors of the analyzed initiatives are estimates.
} 